\title{
Modernism in Art, \\ Design and Architecture
}




\section{Modernism in Art, \\ Design and Architecture}

CHRISTOPHER CROUCH 


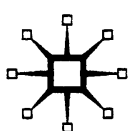

(c) Christopher Crouch 1999

Softcover reprint of the hardcover 1st edition 1999

All rights reserved. No reproduction, copy or transmission of this publication may be made without written permission.

No paragraph of this publication may be reproduced, copied or transmitted save with written permission or in accordance with the provisions of the Copyright, Designs and Patents Act 1988, or under the terms of any licence permitting limited copying issued by the Copyright Licensing Agency, 90 Tottenham Court Road, London W1T 4LP.

Any person who does any unauthorised act in relation to this publication may be liable to criminal prosecution and civil claims for damages.

The author has asserted his right to be identified as the author of this work in accordance with the Copyright, Designs and Patents Act 1988.

Published by PALGRAVE MACMILLAN

Houndmills, Basingstoke, Hampshire RG21 6XS and 175 Fifth Avenue, New York, N. Y. 10010 Companies and representatives throughout the world

PALGRAVE MACMILLAN is the global academic imprint of the Palgrave Macmillan division of St. Martin's Press, LLC and of Palgrave Macmillan Ltd. Macmillan ${ }^{\circledR}$ is a registered trademark in the United States, United Kingdom and other countries. Palgrave is a registered trademark in the European Union and other countries.

ISBN 978-0-333-64285-6 ISBN 978-1-349-27058-3 (eBook) DOI 10.1007/978-1-349-27058-3

Outside North America

ISBN 978-0-333-64284-9 hardback

ISBN 0-333-64284-8 hardback

Inside North America

ISBN 978-0-312-21830-0 hardback

ISBN 978-0-312-21832-4 paperback

This book is printed on paper suitable for recycling and made from fully managed and sustained forest sources.

A catalogue record for this book is available from the British Library.

A catalogue record for this book is available from the Library of Congress. 


\section{Contents}

List of Illustrations vi

Acknowledgements viii

$\begin{array}{ll}\text { Introduction } & 1\end{array}$

1 The Cultural Background to the Machine Age 10

2 The Arts and Crafts - Revolution and Rusticity, New

Languages for Design 29

3 The Machine Ethic - Functionalism and the Collective 46

4 Individualism - The Expressive Voice and the Unconscious

5 The Modernist Mass Media 92

6 Realism and Objectivity 112

7 High Modernism? Or Modernism in Crisis? 139

8 After Modernism? Or Developing Modernism? 162

9 Coda 180

$\begin{array}{ll}\text { Notes } & 187\end{array}$

$\begin{array}{ll}\text { Index } & 198\end{array}$ 


\section{List of Illustrations}

1.1 The Engine Shed at Campden Town, London, 1847. Illustrated London News.

2.1 Edward William Godwin, side chair, 1887. Ebonised wood. Collection, Art Gallery of Western Australia.

2.2 Charles Rennie Mackintosh, Willow, 1904. Ebonised wood. Collection, Art Gallery of Western Australia

2.3 Emile Gallé, Vase de Tristesse, 1890. Carved glass. Collection, Art Gallery of Western Australia.

3.1 Gino Severini, Musicians, 1912. Oil on cardboard. Collection, Art Gallery of Western Australia.

3.2 El Lasar Lissitzky, Proun, 1923. Lithograph with collage. Collection, Art Gallery of Western Australia.

3.3 After Louis Losowick, Tatlin's Monument to the Third International, 1920. Woodcut.

3.4 Izvestia Building, Moscow, 1925. Grigory Borisovich Barkin.

3.5 Red Sport International Stadium, Kharkov, c. 1928. A. Nicholsky, K. Kashin.

4.1 Wassily Kandinsky, The Great Resurrection, 1911. Woodcut. Collection, Art Gallery of Western Australia.

5.1 Varvara Stepanova, Playbill, c.1923. Private collection.

5.2 Andy Warhol, Marilyn, 1967. Screenprint. Collection, Art Gallery of Western Australia.

6.1 W. Frank Calderon, A Son of Empire, 1899. Oil on canvas. Present whereabouts unknown.

6.2 Arthur Streeton, Chelsea, 1905. Collection, Art Gallery of Western Australia.

6.3 Yuri Pimenov, New Moscow, 1937. Collection, Tretyakov Gallery.

6.4 Moscow State University, 1949. L. V. Rudnov, S. Chernyshev, P. Abromisov, A. Khryakov.

6.5 Vera Mukhina, Worker and Collective-Farm Woman, 1937.

6.6 Sui Kei-Min, Sunrise at the Refinery, 1972. Woodcut. 137

7.1 New York, the paradigm of the modernist city. 
7.2 Frank Stella, Polar Co-ordinates for Ronnie Peterson VIII, 1980. Screenprint. Collection, Art Gallery of Western Australia.

7.3 After Walter Teague, prototype design for rear-engined car, 1938.

7.4 Checker cars: doomed for failure in an age of planned obsolescence. Checker cars advertisement, 1967.

7.5 Buckminster Fuller, geodesic dome patent, 1954.

8.1 Alan Cruickshank, 'The Arcanum Museum: Ross and Keith Smith, Pioneer Aviators', 1996. Digital cibachrome. Collection, Art Gallery of Western Australia. 
viii

\section{Acknowledgements}

The author wishes to thank Jane Pearce for her help in the writing of this book, Kathryn Kiely for her help with illustrations, and The Art Gallery of Western Australia.

C.C. 